\title{
Characteristics of Entisol Treated With Pulp Residue and Fertilizer in Eucalyptus Plantation
}

\author{
Elizeu de Souza Lima ${ }^{1}$, Zigomar Menezes de Souza ${ }^{1}$, Rafael Montanari ${ }^{2}$, Alan Rodrigo Panosso ${ }^{3}$, \\ Ingrid Nehmi de Oliveira ${ }^{1}$, Lenon Henrique Lovera ${ }^{1}$, Diego Alexander Aguilera Esteban ${ }^{1}$ \\ \& Christtiane Fernandes Oliveira ${ }^{1}$ \\ ${ }^{1}$ College of Agricultural Engineering, Faculty of Agricultural Engineering, State University of Campinas, \\ Campinas, São Paulo, Brazil \\ ${ }^{2}$ Department of Phytosanity, Rural and Soil Engineering, State University of São Paulo, Ilha Solteira, São Paulo, \\ Brazil \\ ${ }^{3}$ Department of Exact Sciences, State University of São Paulo, Jaboticabal, São Paulo, Brazil \\ Correspondence: Elizeu de Souza Lima, College of Agricultural Engineering, Faculty of Agricultural \\ Engineering, State University of Campinas, Av. Cândido Rondon, 501, Barão Geraldo, 13.083-875, Campinas, \\ São Paulo, Brazil. E-mail: elizeu.florestal@gmail.com
}

$\begin{aligned} & \text { Received: December 15, } 2018 \quad \text { Accepted: February 21, } 2019 \quad \text { Online Published: May 31, } 2019 \\ & \text { doi:10.5539/jas.v11n7p1 }\end{aligned}$ URL: https://doi.org/10.5539/jas.v11n7p1

\begin{abstract}
The purpose of this study was to identify, through multivariate analyzes, the physical and chemical characteristics of the soil that best explain the initial development of eucalyptus treated with limestone and lime sludge. This study was conducted in 2014 in the municipality of Três Lagoas (MS). Three treatments were experimented corresponding to the applications of (i) limestone, (ii) lime sludge, and (iii) control or application of neither limestone nor lime sludge. The principal components analysis identified that Group 1 assembling gravimetric moisture, hydrogen potential, calcium and aluminum and, Group 2 composed of contents of sand, clay, phosphorus and organic matter explained $54.96 \%$ of the total variability that showed higher discriminatory power of eucalyptus height and diameter variation at breast height. The treatment with limestone showed a contrast between high $\mathrm{pH}$ and high $\mathrm{Ca}$ content, but low levels of aluminum.
\end{abstract}

Keywords: lime sludge, multivariate analysis, soil physical and chemical characteristics, soil handling

\section{Introduction}

Commercial eucalyptus farming has been increasingly recommended for pulp and paper production, due to its excellent volumetric yield and good wood quality. This good performance of the crop is a result of combined actions that include intense genetic improvement of the species, proper management of plantation and the use of tools that support the decision-making process to increase wood productivity (Silva et al., 2016).

The area covered with eucalyptus in Brazil is significant; around 5.6 million hectares. It is the fourth crop in total area cultivated in the country, behind soybean, corn and sugar cane (Perpetua et al., 2017). The development of the Brazilian forest-based industry is a result of high productivity of the trees planted in the country, reaching on average $36 \mathrm{~m}^{3} \mathrm{ha}^{-1}$ year $^{-1}$ for eucalyptus (IBÁ 2017; Nogueira Filho et al., 2017). At the same time, the exported volume of pulp has increased in recent years, making Brazil the world's fourth largest producer of eucalyptus and the second largest exporter of pulp, with 18.8 million tons per year (IBÁ, 2017).

In the current context of eucalyptus expansion, a more sustainable production should be considered. However, this concept directly involves sustainability of the soil and the environment, which depend on factors such as management decisions made by producers in the forest community and other agricultural managers, incentives to soil conservation, and the use of industrial waste as forest soil fertilizers (Keesstra et al., 2016).

In the search for sustainable production of eucalyptus, the residues from wood processing for pulp production have been used as forest soil correctives and fertilizers (Rodriguez et al., 2018). These residues have been used as soil conditioners and as a source of nutrients, resulting in improved soil characteristics required for the economic development of forest plantations (Maciel et al., 2015). 
These residues include lime sludge, a product of the lime calcination process for pulp extraction, which presents high levels of calcium (Ca), similar to those found in calcitic limestone; when used in the soil, it reduces acidity and the content of aluminum (Al) and increases the content of $\mathrm{Ca}$ and sodium (Na) in the soil (Simonete et al., 2013; Maeda et al., 2015).

The great challenge of sustainability studies is related to the development of methods to evaluate soil quality, plant development and the environment under human interference. A multidisciplinary effort is currently observed that quantifies different physical and chemical characteristics of soil and plants related to sustainability, translating them into soil quality indicators (Coutinho et al., 2017).

A soil quality indicator can be simply a measurable variable (soil characteristic), a process (nutrient mineralization rate), or an index, which includes several soil measurements (soil density, soil porosity, organic matter and others) (Freitas et al., 2017). Land use in the production process of eucalyptus changes the physical and chemical characteristics of the soil in relation to its natural condition, which can cause soil degradation. Therefore, to ensure sustainability of this process, practices should be adopted to quantify such changes through monitoring and measurements of soil characteristics (Ferreira et al., 2018), which requires different statistical techniques that evaluate soil changes.

With multivariate techniques, it is possible to describe similarities between the samples, generating a grouping of sampling points, and discriminate soil characteristics with more variables from the original data. These evaluations would not be possible with univariate statistics (Albuquerque et al., 2015). Multivariate techniques allow simultaneous evaluation of many characteristics taking into account and the correlations between them (Paye et al., 2012).

Techniques like cluster analysis, complemented with the principal component analysis, can be applied in this context. Its purpose is to explain the multivariate structure of the original data, condensing relevant information into orthogonal axes called principal components, and graphs like dendrogram present a subdivision of groups and seek maximum homogeneity between the samples in the group and maximum heterogeneity between the groups (Cheng et al., 2016; Khaledian et al., 2017). Therefore, this approach can identify which physical and chemical characteristics of the soil directly influence the initial growth of eucalyptus, thus eliminating the analysis of characteristics that express poor response to eucalyptus development (Silva et al., 2015).

Considering the above, the research hypothesis was that the highest eucalyptus, eucalyptus diameter at breast height and soil nutrient contents would occur with the application of lime sludge + oxyfertil sludge when compared to the application of limestone and the control. Therefore, the objective of this work was to identify, by means of multivariate analyses, the physical and chemical characteristics of the soil that best explain the initial development of eucalyptus treated with limestone and lime sludge.

\section{Material and Methods}

This study was conducted in the cropping year 2014/2015, in Fazenda Bom Retiro the experimental area owned by Eldorado Brasil Celulose in the municipality of Três Lagoas, MS, located $20^{\circ} 27^{\prime}$ South latitude and $52^{\circ} 29^{\prime}$ West longitude. The average annual rainfall was $1,300 \mathrm{~mm}$, and the average temperature $23.7^{\circ} \mathrm{C}$. The climate is type Aw (Alvares et al., 2013), characterized as tropical humid with the rainy season in the summer and the dry season in winter. The soil was classified as an Entisol on the basis of the USDA Soil Taxonomy.

In March 2014, soil correction was conducted through the application of $2.0 \mathrm{Mg} \mathrm{ha}^{-1}$ dolomitic limestone with $30 \% \mathrm{CaO}, 12 \% \mathrm{MgO}$ and $85 \% \mathrm{RNV}$ (relative neutralizing value) to raise base saturation to $50 \%$, and later Eucalyptus urograndis clone E13 was planted at a spacing of $3.0 \mathrm{~m}$ between rows and $2.5 \mathrm{~m}$ between plants in a raw. The clone E13 was mainly characterised by a rapid growth in height and diameter promoting improved yield, wood of good quality, and vigorous trees. It also presents tolerance to alkalinity and development in sandy soils generally marked by low fertility and low water content.

In June 2014, the area was divided into three experimental grids (grid $1=$ treatment with limestone, grid $2=$ treatment with lime sludge + oxyfertil, grid $3=$ control or no application of neither limestone nor lime sludge), each of approximately 2.0 ha. Grid 1 received $2.0 \mathrm{Mg} \mathrm{ha}^{-1}$ dolomitic limestone. Grid 2 received $2.0 \mathrm{Mg} \mathrm{ha}^{-1}$ lime sludge + oxyfertil containing $60 \%$ lime sludge and $40 \%$ oxyfertil. Lime sludge consisted of $24 \% \mathrm{CaO}$ and $0.1 \%$ $\mathrm{MgO}$, and oxyfertil consists of $60 \% \mathrm{CaO}$ and $30 \% \mathrm{MgO}$. Grid 3 received no soil correction treatment. The applications of dolomitic limestone and lime sludge + oxyfertil were performed with a Tatu Marchesan model DCA 7500 spreader (Marchesan implements and Agricultural Machinery, Matão, Brazil) connected to a Valtra BM110 $4 \times 4$ tractor (Valtractor Trade in Tractors and Agricultural Machines, Suolahti, Finlândia). The spreader was calibrated for each type of application. 
$\mathrm{X}$ and $\mathrm{Y}$ directions of the Cartesian coordinate system were defined and general staking of the experimental grids was performed according to eucalyptus spacing. The experimental grid had 5 transections, each containing 10 collection points, totaling 50 sampling points in each experimental grid. Each transection followed the planting of eucalyptus in rows, and the spacing between soil and plant sampling points was $7.5 \times 3.0 \mathrm{~m}$.

Soil and plant characteristics were analyzed around each tree representing the sampling point three months after the application of the lime sludge + oxyfertyl and limestone and six months after planting eucalyptus. The plant characteristics evaluated were (i) the tree height (HEI), measured with a ruler graduated in meters, and (ii) the diameter at breast height (DBH) measured at $1.30 \mathrm{~m}$ from the ground using a digital caliper.

To determine the soil physical and chemical characteristics, deformed and undeformed samples of the soil were collected from 0-20 cm layer. The physical characteristics evaluated were (i) soil resistance to penetration (RP), (ii) gravimetric moisture (GM), and (iii) granulometry (sand, silt and clay). Penetration resistence penetration was determined according to the methodology of Stolf et al. (2014), gravimetric moisture and granulometry according to the methodology described by Embrapa (2017).

The content of calcium $\left(\mathrm{Ca}^{2+}\right)$, magnesium $\left(\mathrm{Mg}^{2+}\right)$, potassium $\left(\mathrm{K}^{+}\right)$, aluminum $\left(\mathrm{Al}^{3+}\right)$ and phosphorus $(\mathrm{P})$ availability were extracted with ion exchange resin and soil $\mathrm{pH}\left(\mathrm{CaCl}_{2} 0.01 \mathrm{~mol} \mathrm{~L}^{-1}\right)$ (Raij et al., 2001). Organic carbon was determined using the methodology proposed by Embrapa (2017). Cation exchange capacity (CEC), base saturation $(\mathrm{V})$ and aluminum saturation $(\mathrm{m})$ were deducted from the analyses of the nutrient contents (Raij et al., 2001).

First, for each soil and plant characteristic, a descriptive analysis was performed through classical statistics using software R of public domain (R Core Team, 2017). For multivariate statistics, three methods were applied: (i) hierarchical cluster analysis, calculates the Euclidean distance between the accesses, for the set of variables and for obtaining the groups of similar accesses; (ii) non-hierarchical cluster analysis (k-means), belongs to the class of non-hierarchical and unsupervised grouping methods. This method minimizes the variance of accesses within each group; and (iii) principal component analysis (PCA), it groups the original data into two latent orthogonal variables called principal components, which are linear combinations created with the two largest eigenvalues of the data covariance matrix. To reduce errors due to the scales and units of variables, all multivariate analyses were performed after standardization of variables, each with mean 0 and variance 1.

Principal component analysis was applied to all soil and plant characteristics to explain the multivariate structure contained in the initial data set; these components were extracted in order of decreasing importance in terms of contribution to explain the total variation of data (Silva et al., 2010a). In this application, a smaller set was obtained of latent (non-measured), orthogonal variables without interrelation called principal components, which were generated from linear combinations between the original variables, based on the eigenvalues of the covariance matrix between data (Johnson \& Wichern 2007; Hair Junior et al., 2009).

The principal components with eigenvalues greater than 1 were considered (Kaiser 1958). The coefficients of linear functions that define the principal components were used in the interpretation of their meaning, using the signal and the relative size of coefficients as an indication of the weight to be assigned to each variable, thus estimating its discriminatory power. These correlations were classified according to Coelho (2005), where the criterion for the classification of eigenvectors - values that represent the weight of each character in each component ranging from -1 to +1 - was: absolute value $<0.30$ : classified as not significant; $0.30-0.40$ : medium significance; and $\geq 0.50$ : very significant. Then, the variables with $\geq 0.50$ (very significant) eigenvectors were submitted to a new PCA to rank the components with higher factorial load (score).

Subsequently, data were submitted to a hierarchical cluster analysis adopting the Euclidean distance as a measure of similarity between the samples and the Ward method as the cluster analysis method. After adopting a number of groups that best characterized the structure of the original data, a non-hierarchical cluster analysis was performed using the k-means algorithm (Hair Junior et al., 2009) to characterize the pattern of the variables from each group using the software Statistica 7.0 (Statsoft, 2005).

\section{Results}

The mean values for Eucalyptus urograndis clone E13 were $3.43 \mathrm{~m}$ in the treatment with limestone, $3.51 \mathrm{~m}$ in treatment with lime sludge and $3.24 \mathrm{~m}$ in the control treatment (Table 1). The mean values of diameter at breast height were $3.0 \mathrm{~cm}$ for dolomitic limestone, $2.7 \mathrm{~cm}$ for lime sludge and $2.2 \mathrm{~cm}$ for control.

The mean values of soil resistance to penetration were $0.60 \mathrm{MPa}$ in the treatment with limestone, $0.80 \mathrm{MPa}$ with lime sludge, and $0.94 \mathrm{MPa}$ in the control (Table 1). The gravimetric moisture was $0.03 \mathrm{~kg} \mathrm{~kg}^{-1}$ in all treatments, which was considered low. 
The mean values for soil chemical attributes related to fertility presented low nutrient content in all treatments (Table 1), except for calcium and magnesium in the treatment with limestone, which were 11.74 and 9.46 mmol $_{\mathrm{c}}$ $\mathrm{dm}^{-3}$, respectively.

According to Pimentel-Gomes and Garcia (2002), the variability of an attribute can be classified according to the magnitude of its coefficient of variation. Height (HEI) presented medium variability for the treatment with limestone $(\mathrm{CV}=20.14 \%)$ and lime sludge $(\mathrm{CV}=18.23 \%)$ and high variability for the control $(\mathrm{CV}=26.58 \%)$. The diameter at breast height $(\mathrm{DBH})$ showed high under limestone and lime sludge applications with $\mathrm{CV}=20.14 \%$ and $\mathrm{CV}=23.45 \%$, respectively, but a very high variability for the control $(\mathrm{CV}=34.63 \%)$.

Table 1. Physical and chemical characteristics of the soil collected from the 0-20 cm layer treated with limestone, lime sludge and the control

\begin{tabular}{|c|c|c|c|c|c|c|c|c|c|c|c|c|c|c|c|c|c|c|}
\hline Statistics & HEI & DBH & $\mathrm{RP}$ & GM & SAND & SIL & CLAY & $\mathrm{P}$ & $\mathrm{OM}$ & $\mathrm{pH}$ & $\mathrm{K}$ & $\mathrm{Ca}$ & $\mathrm{Mg}$ & $\mathrm{Al}$ & SB & $\mathrm{CEC}$ & $\mathrm{V}$ & $\mathrm{m}$ \\
\hline & \multicolumn{2}{|c|}{------ m ----- } & $\mathrm{MPa}$ & $\mathrm{kg} \mathrm{kg}^{-1}$ & - & $\mathrm{gkg}^{-1}$ & --- & $\mathrm{mg} \mathrm{dm}{ }^{-3}$ & $\mathrm{~g} \mathrm{dm}^{-3}$ & & \multicolumn{6}{|c|}{ - } & \multicolumn{2}{|c|}{------ \% ----- } \\
\hline \multicolumn{19}{|l|}{ Limestone } \\
\hline Mean & 3.43 & 0.030 & 0.60 & 0.03 & 903.99 & 28.96 & 67.05 & 2.72 & 11.14 & 4.53 & 0.78 & 11.14 & 9.46 & 6.26 & 20.74 & 41.09 & 46.74 & 30.34 \\
\hline Median & 3.50 & 0.031 & 0.55 & 0.02 & 904.75 & 29.15 & 69.10 & 2.00 & 11.00 & 4.00 & 0.80 & 11.50 & 9.00 & 6.00 & 21.15 & 40.20 & 51.07 & 20.00 \\
\hline $\mathrm{CV}(\%)$ & 20.14 & 20.14 & 16.32 & 25.71 & 1.13 & 31.45 & 5.89 & 29.75 & 10.42 & 0.77 & 24.30 & 76.53 & 71.42 & 69.80 & 65.17 & 27.10 & 46.29 & 91.29 \\
\hline CK & -0.62 & -0.62 & 4.42 & -0.13 & -0.26 & -0.64 & -0.54 & 0.05 & 0.47 & -0.75 & 1.06 & 0.71 & 1.02 & -1.13 & -0.03 & 0.32 & -1.09 & -0.94 \\
\hline $\mathrm{CA}$ & -0.59 & -0.59 & 2.20 & 0.69 & -0.13 & 0.14 & -0.35 & 0.56 & 0.86 & 0.29 & 0.71 & 0.91 & 1.05 & 0.37 & 0.62 & 0.77 & 0.29 & 0.78 \\
\hline \multicolumn{19}{|c|}{ Lime sludge } \\
\hline Mean & 3.51 & 0.027 & 0.80 & 0.03 & 888.9 & 31.91 & 79.19 & 2.98 & 11.52 & 4.14 & 0.60 & 3.28 & 4.20 & 10.30 & 8.63 & 35.51 & 26.02 & 56.24 \\
\hline Median & 3.60 & 0.028 & 0.79 & 0.03 & 888.20 & 32.90 & 78.35 & 3.000 & 11.00 & 4.00 & 0.50 & 2.00 & 3.00 & 12.00 & 5.85 & 35.45 & 17.00 & 67.5 \\
\hline $\mathrm{CV}(\%)$ & 18.23 & 23.45 & 27.97 & 18.91 & 0.82 & 17.91 & 6.90 & 22.98 & 11.13 & 11.00 & 48.65 & 86.46 & 84.15 & 47.69 & 93.28 & 15.02 & 85.87 & 51.02 \\
\hline CK & 0.03 & 0.20 & 0.22 & -0.13 & 0.10 & -0.94 & 1.32 & 1.83 & 1.09 & 5.77 & 0.13 & 0.71 & 5.80 & -0.57 & 7.80 & 2.26 & 1.78 & -0.85 \\
\hline $\mathrm{CA}$ & -0.63 & -0.83 & 0.71 & 0.18 & 0.19 & -0.44 & 0.75 & 0.82 & 0.98 & 1.51 & 0.79 & 1.17 & 2.23 & -0.73 & 2.50 & 1.04 & 1.58 & -0.70 \\
\hline \multicolumn{19}{|l|}{ Control } \\
\hline Mean & 3,24 & 0.022 & 0.94 & 0.03 & 894.56 & 33.03 & 72.00 & 2.30 & 11.50 & 4.28 & 0.76 & 4.88 & 4.64 & 10.14 & 10.84 & 35.89 & 26.64 & 55.1 \\
\hline Median & 3.32 & 0.023 & 0.69 & 0.03 & 894.25 & 34.15 & 72.70 & 2.00 & 11.00 & 4.10 & 0.70 & 3.00 & 3.00 & 12.00 & 6.40 & 34.95 & 20.00 & 64.00 \\
\hline CV (\%) & 26.58 & 34.63 & 59.92 & 19.92 & 0.89 & 14.46 & 7.21 & 36.48 & 14.33 & 11.22 & 50.78 & 123.07 & 101.16 & 54.60 & 107.48 & 16.93 & 79.75 & 55.33 \\
\hline CK & -0.39 & -0.24 & 2.24 & -0.61 & 0.05 & -0.39 & -0.62 & 1.39 & 1.73 & 0.55 & 1.54 & 4.79 & 3.11 & -0.85 & 3.88 & 1.88 & 0.26 & -0.87 \\
\hline CA & -0.55 & -0.17 & 1.77 & -0.38 & 0.28 & -0.78 & -0.54 & 0.88 & 1.05 & 1.28 & 1.26 & 2.24 & 1.86 & -0.75 & 2.04 & 1.04 & 1.20 & -0.77 \\
\hline
\end{tabular}

Note. $\mathrm{HEI}=$ height of trees; $\mathrm{DBH}=$ diameter at breast height; RP = soil resistance to penetration; GM = gravimetric moisture; $\mathrm{SIL}=$ silt; $\mathrm{P}=$ phosphorous; $\mathrm{OM}=$ organic matter; $\mathrm{pH}=$ hydrogen potential; $\mathrm{K}=$ potassium; $\mathrm{Ca}=$ calcium; $\mathrm{Mg}=$ magnesium; $\mathrm{Al}=$ aluminum; $\mathrm{SB}=$ sum of bases; $\mathrm{CEC}=$ cation-exchange capacity; $\mathrm{V}=$ base saturation; $\mathrm{m}=$ aluminum saturation; $\mathrm{CV}=$ coefficient of variation; $\mathrm{CK}=$ coefficient of kurtosis; $\mathrm{CA}=$ coefficient of asymmetry.

The physical characteristics of the soil presented coefficients of variation from low to very high (Table 1). Sand and clay presented low CVs, ranging from 0.82 to $7.21 \%$. The coefficients of variation for soil resistance to penetration (RP) were medium to very high, and medium to high for gravimetric moisture (GM).

The variability of most chemical characteristics of the soil was very high. It was the cases for $\mathrm{K}, \mathrm{Ca}, \mathrm{Mg}, \mathrm{Al}, \mathrm{SB}$, $\mathrm{V}$, and $\mathrm{m}$ whose CVs ranged between $46.29 \%$ and $123.07 \%$ for the three treatments although the greatest variability, in absolute terms, was found for the control plots i.e. plots without soil corrective and/or fertilizer. The $\mathrm{P}, \mathrm{OM}, \mathrm{pH}$, and CEC presented low to high variability as their CVs varied between $0.77 \%$ and $27.10 \%$. In fact, the lowest CVs were recorded for the treatment with limestone and the high for the control.

The values of positive asymmetry for RP, $\mathrm{P}, \mathrm{OM}, \mathrm{pH}, \mathrm{K}, \mathrm{Ca}, \mathrm{Mg}, \mathrm{SB}, \mathrm{CEC}$, and $\mathrm{V}$ in both the limestone and lime sludge treatments were globally below the observed mean, with such trend becoming more expressive as values increased. An opposite situation was observed for negative values of asymmetry obtained for HEI, DBH, SIL, and $\mathrm{m}$. The characteristics that presented a platykurtic distribution for the two treatments were RP, P, OM, K, Ca, $\mathrm{Mg}$, and CEC. The GM, SIL, Al and $\mathrm{m}$ had a leptokurtic distribution in both the limestone and lime sludge treatments, showing that a minority of soil attributes has data close to the center in the frequency distribution graph.

In the principal component analysis, the first two principal components (PC1 and PC2) were considered as they can simultaneously retain enough the total information contained in the set of original variables for each treatment, which was defined by 18 attributes, allowing to illustrate their locations in a biplot (Figure 1). At first, 
the intention was to analyze the relationship between soil attributes and the different treatments. In the PCA, a set of plant and soil physical and chemical attributes was used for the 0-20 cm layer, considering the first two principal components only (Figure 1). These two main components explained $54.96 \%$ of the total variability contained in the parameters considered i.e. 35.19 and 19.77\% for CP1 and CP2, respectively (Figure 1).

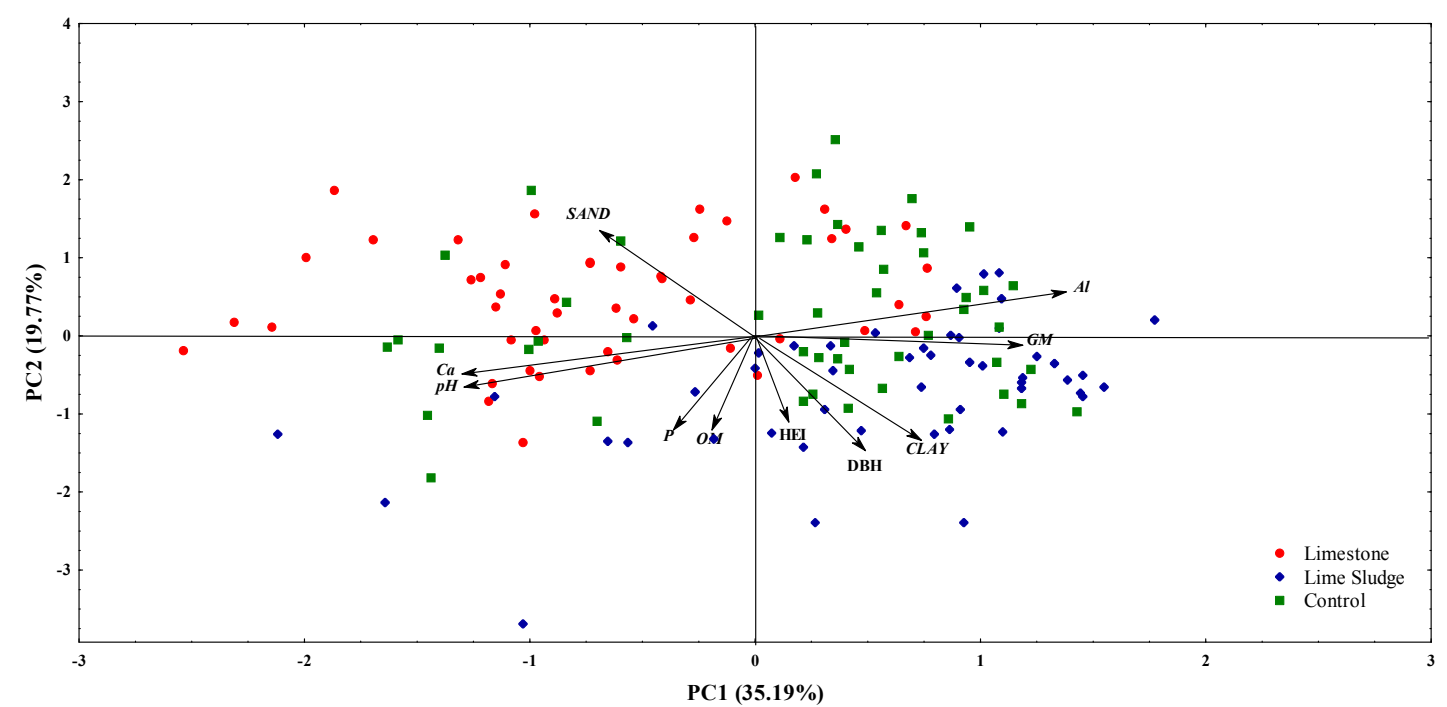

Figure 1. Biplot of principal components generated from the plant and soil 0-20 cm layer's attributes following applications of limestone, lime sludge, and control

Note. $\mathrm{HEI}=$ height of eucalyptus; $\mathrm{DBH}=$ diameter at breast height of eucalyptus; $\mathrm{Ca}=$ calcium content; $\mathrm{pH}=$ hydrogen potential; $\mathrm{P}=$ phosphorus content; $\mathrm{OM}=$ organic matter; $\mathrm{Al}=$ aluminum content; $\mathrm{GM}=$ gravimetric moisture.

The of plant and soil attributes in the treatment with limestone application are mostly in quadrant 4 (left side of the biplot), influenced by negative values of PC1 (Figure 1), which indicates high pH and high Ca at these points, as expected; in contrast, these samples presented low values of gravimetric moisture and aluminum (Table 2).

The control was the most scattered among the treatments, mostly in quadrants 1 and 2 (right side of the biplot), that is, it presented a subgroup of points providing a contrast between $\mathrm{Ca}$ and $\mathrm{pH}, \mathrm{Al}$ and GM, where, $\mathrm{Al}$ and $\mathrm{GM}$ presented high values influenced by positive values of PC1, while the treatment with lime sludge + oxyfertil was mostly in quadrant 2, a contrast between HEI, DBH and clay versus sand, influenced by negative values of PC2.

In the PCA with the variables of higher scores, two principal components were extracted, which accounted for $54.96 \%$ of the total data variability (Table 2). The first component explained $35.19 \%$ of the total variability of the parameters analyzed from the experimental area, showing significant correlations with the $\mathrm{GM}, \mathrm{pH}, \mathrm{Ca}$ and $\mathrm{Al}$ for the $0-20 \mathrm{~cm}$ layer, where $\mathrm{pH}$ and calcium correlated negatively, while volumetric moisture and aluminum correlated positively. The second principal component explained $19.77 \%$ of data variability and showed significant correlations with diameter at breast height, sand, clay, phosphorus content, and organic matter of the soil. However, only sand had a positive correlation with the PC2, the other attributes correlated negatively. 
Table 2. Correlation coefficients of principal components through a multivariate analysis of plant and soil attributes for the $0-20 \mathrm{~cm}$ layer

\begin{tabular}{lll}
\hline Attributes & PC1 & PC2 \\
\hline HEI (height of eucalyptus) & 0.106 & -0.445 \\
DBH (diameter at breast height) & 0.283 & $-0.587^{*}$ \\
GM (gravimetric moisture) & $0.789^{*}$ & -0.066 \\
Sand & -0.462 & $0.551^{*}$ \\
Clay & 0.477 & $-0.601^{*}$ \\
P (phosphorus) & -0.239 & $-0.539^{*}$ \\
OM (organic matter) & -0.128 & $-0.553^{*}$ \\
pH (hydrogen potential) & $-0.854^{*}$ & -0.294 \\
Ca (calcium) & $-0.859^{*}$ & -0.213 \\
Al (aluminum) & $0.907 *$ & 0.191 \\
\hline Eigenvalue & 3.421 & 1.878 \\
\hline Variance explained $(\%)$ & 35.19 & 19.77 \\
\hline
\end{tabular}

Note. ${ }^{*}$ Correlations considered in principal component interpretation.

The correlation of variables and the plot for the principal components show the variables that best discriminated the formation and differentiation of the environments (Table 2 and Figures 1 and 2). GM was responsible of separating the treatments of lime sludge + oxyfertil from limestone and control, while OM separated limestone from the other treatments (Figure 1). For the grouping in the limestone treatment, the attributes of stronger influence were sand, $\mathrm{Ca}, \mathrm{pH}$, then HEI, DBH and clay for the grouping in the treatment with lime sludge + oxyfertil, and both the $\mathrm{Al}$ and GM for the control, although more diffuse.

The dendrograms obtained from the hierarchical cluster analysis, in which the expressive variation in the Euclidean distance values between the accessions for the set of variables enables a division of groups in each treatment (Figure 2). The expressive variation in the Euclidean distance values between the accessions for the set of variables considered creates four groups for the treatment with limestone, two groups for the treatment with lime sludge + oxyfertil, and three groups for the control with homogeneous graphs.

In this analysis, the soil samples were grouped according to their degree of similarity, aiming to classify them into homogeneous groups (Figure 2). Then, a cutoff was used in the Euclidean distance of 9, 14 and 15 for limestone, lime sludge + oxyfertil and control, respectively. The use of the data set for the plant, physical and chemical soil characteristics allowed data arrangement into groups, according to the respective treatment.
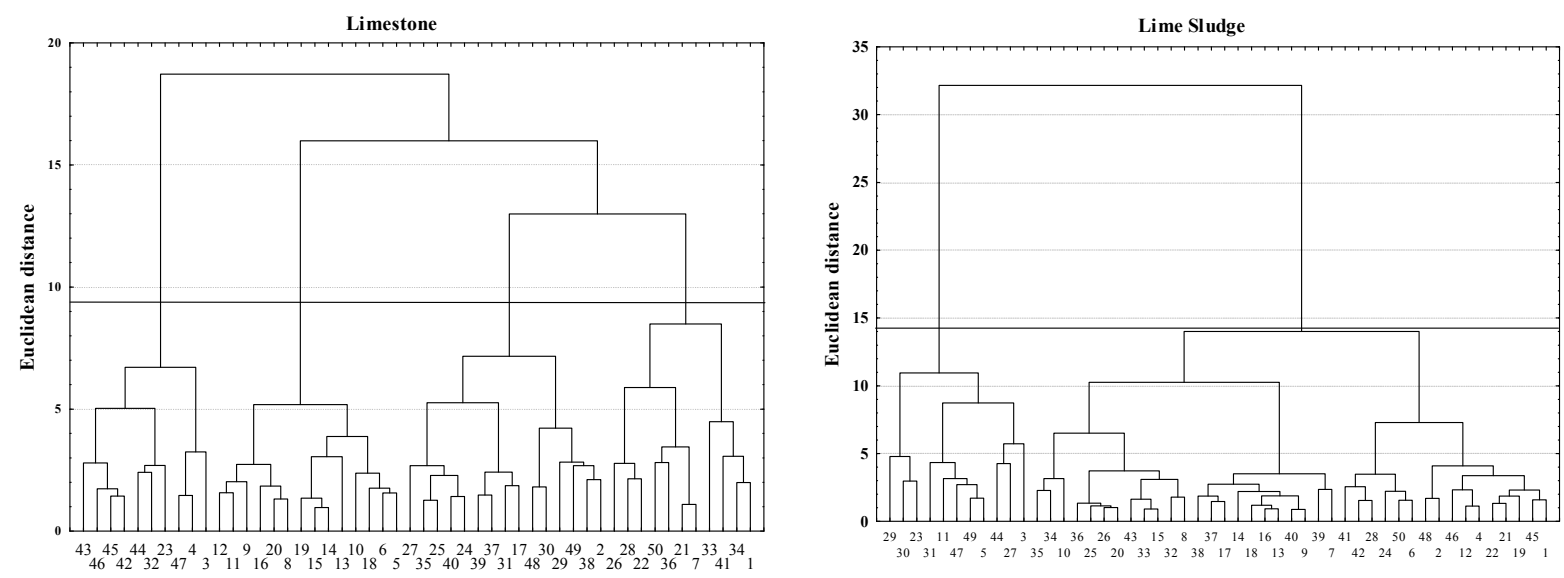


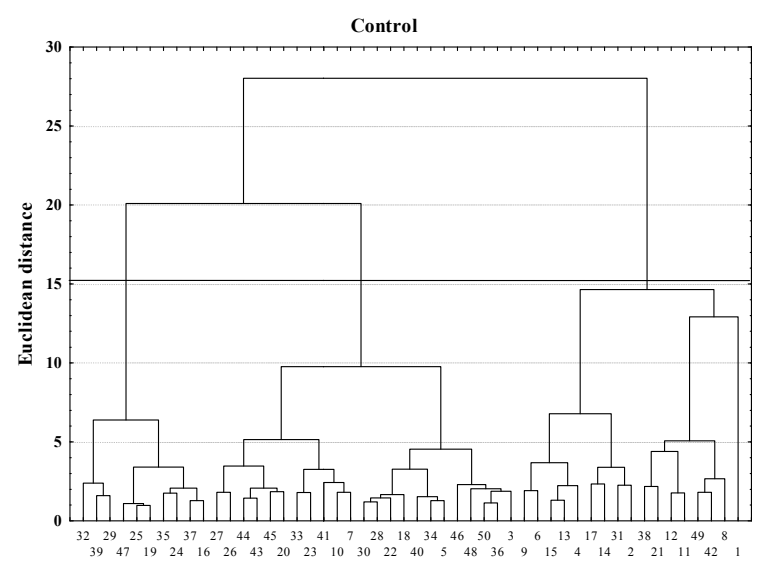

Figure 2. Dendrogram resulting from the hierarchical cluster analysis showing the formation of groups generated from plant and soil attributes for the treatments with limestone, lime sludge and control in the $0-20 \mathrm{~cm}$ layer

Figure 3 shows the positions of groups/clusters in the experimental area from the dendrogram divisions, where the limestone treatment presented 4 groups, lime sludge 3 and control 4 . In the treatment with limestone, group 3 accounted for $32 \%$ of the total area, mostly located in the central-west portion, followed by group $2(28 \%)$ and groups 1 and $4(20 \%$ each). The treatment of lime sludge + oxyfertil presented two distinct groups, and group 2 corresponding to $78 \%$ of the total area, presenting a wide distribution in the area. On the other hand, the control treatment presented three groups; group 2 accounted for $64 \%$ of the total area, distributed across the evaluated area.

Group 1 presented the highest values of phosphorus, organic matter, diameter at breast height, clay, $\mathrm{pH}$ and calcium (Figure 1); while group 2 showed the highest values of sand, gravimetric moisture and aluminum content.
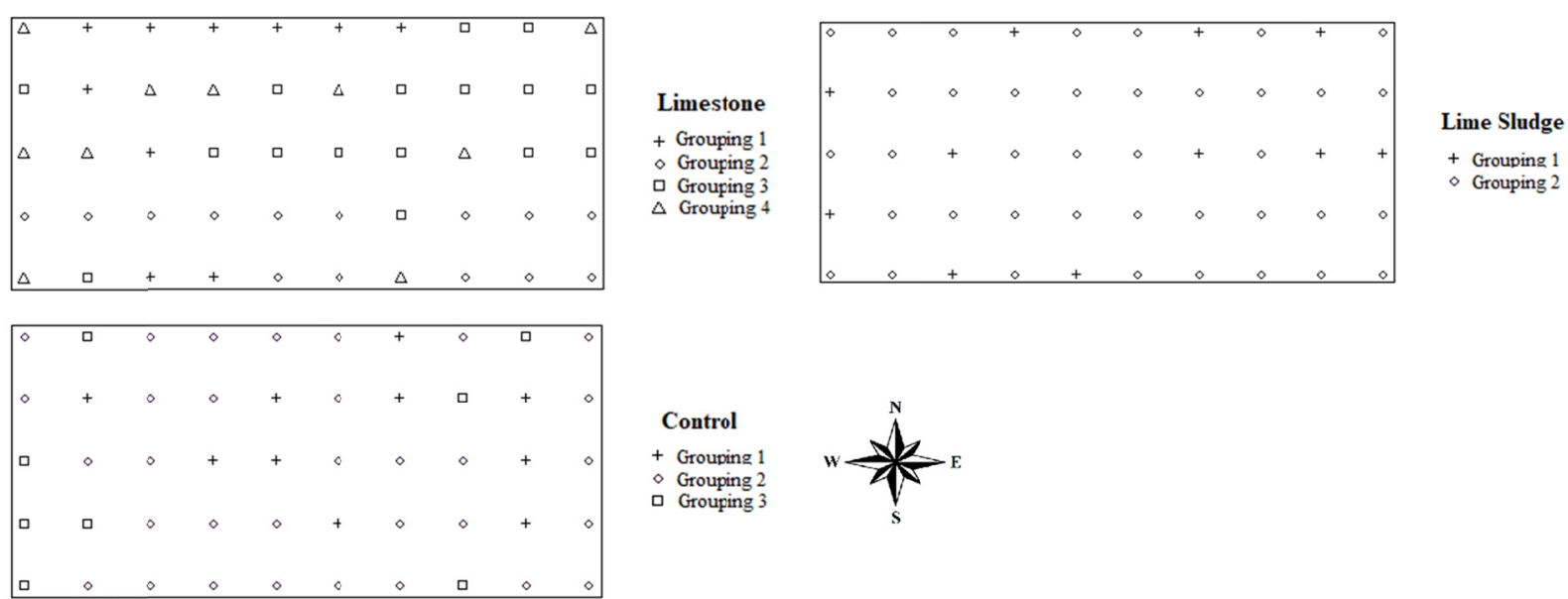

Figure 3. Spatial distribution of the groups generated from the plant and soil attributes after the treatment with limestone, lime sludge and control in the of 0-20 cm layer

Figure 4 shows standardized averages of plant and soil attributes for each group and each treatment, according to non-hierarchical cluster analysis (k-means). For the treatment with limestone, the three groups presented similar patterns, except for group 1, which showed higher values of $\mathrm{Al}$ and consequently lower values of $\mathrm{Ca}$ and $\mathrm{pH}$.

For the control treatment, the groups were very distinct: group 1 had low Al values, resulting in average eucalyptus height, and in group 2, higher Al content in the soil resulted in lower eucalyptus. 

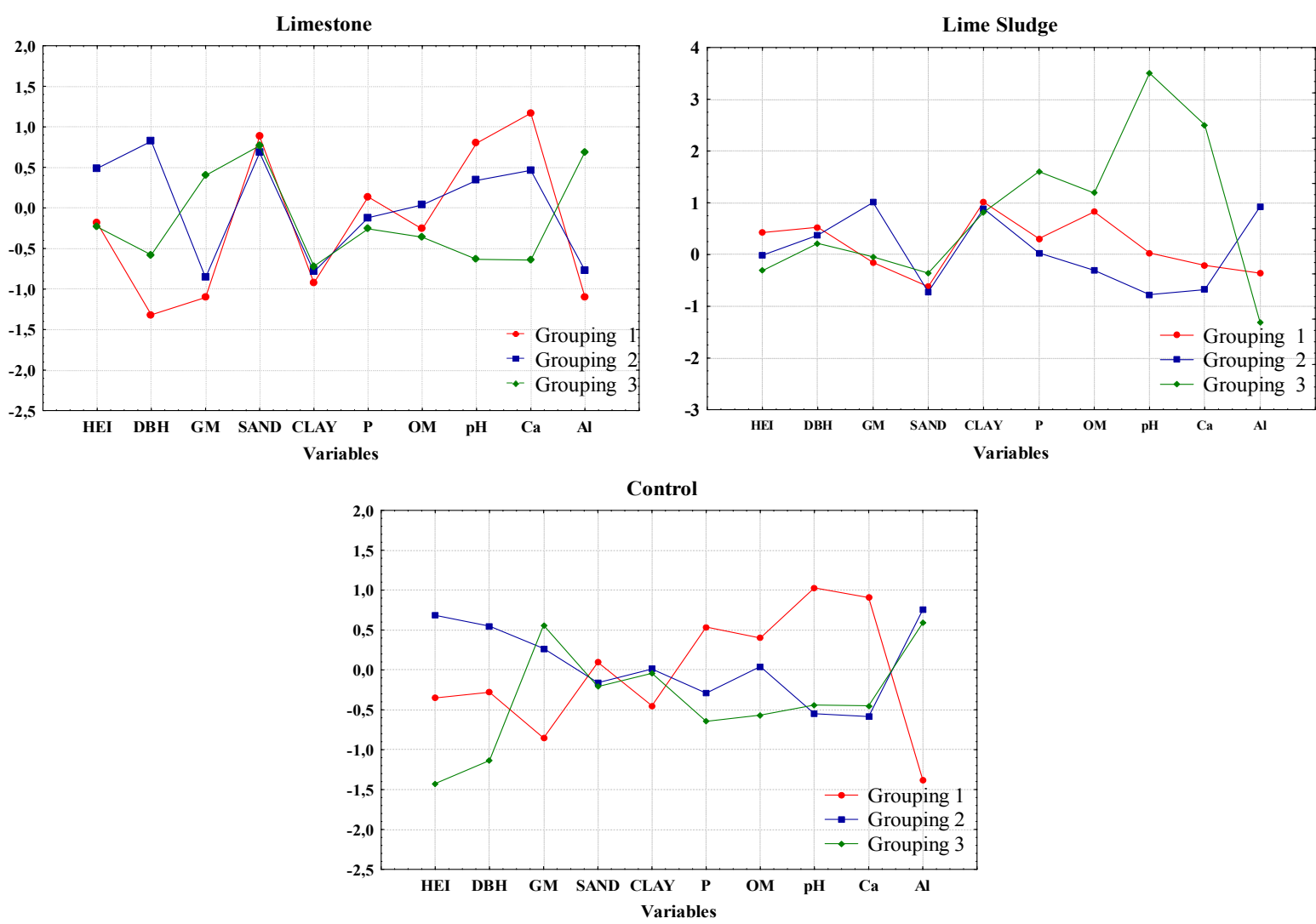

Figure 4. Standardized means generated from plant and soil attributes for each group according to a non-hierarchical cluster analysis (k-means) for treatments with limestone, lime sludge and control in the $0-20 \mathrm{~cm}$ layer

\section{Discussion}

The values of ALT and DAP of eucalyptus obtained at six months of age grown in a sandy soil agree with the literature. When analyzing the initial growth of Eucalyptus urograndis as a function of acclimatization and different soil texture (sandy with $85 \%$ sand and clayey with $60 \%$ clay), Lopes et al. (2011) observed at month six after planting that the eucalyptus cultivated in the clayey soil had a height development of $17.5 \%$ and DBH of $10.85 \%$ higher than the eucalyptus produced in sandy soil. On the other hand, Afzal et al. (2018), when evaluating the initial development of eucalyptus in sandy and clayey soil, found no statistical difference between the two types of soil in both height and for diameter at breast height.

However, Afzal et al. (2018) report that clay soils should be cultivated with agronomic species and sandy soils with forest species. Forest species such as eucalyptus grow in several types of soil (sandy and clayey) because they have long roots that access nutrients and water at greater depths.

The soil in the study area presented RP below 2.0 MPa for the superficial layer of 0-20 cm .A value or range of critical values of soil resistance to penetration that restrict plant growth is desirable by several authors. There is no consensus in the literature on a critical limit for the development of the eucalyptus root system - Reichert et al. (2007) found values close to 2.5 MPa, Magalhães et al. (2001) found 2.2 MPa as the critical value of soil resistance to penetration, and Carvalho et al. (2012) reported values between 2.5 and $3.0 \mathrm{MPa}$ are critical for the full growth of roots from forest species. .

The low compaction is due to soil spraying during soil handling for correction and eucalyptus planting. This fact was observed by Carvalho et al. (2015), who found low soil resistance to penetration in young Eucalyptus urograndis planting on an Entisol in the Cerrado, with all values below 2.0 MPa in the soil surface layer. These results are probably due to the greater anthropogenic interference, that is, soil handling for silviculture of eucalyptus plantation, and the fact that Entisol has a weak structure, offering low soil resistance to penetration and lowsoil water retention. 
An entisol is characterized by a low natural fertility, but soil use and handling can alter its chemical characteristics (Oliveira et al., 2017). Considering the low fertility of these soils where the eucalyptus forests are being implemented, economic and environmentally viable alternatives should be adopted for the production of healthy plants for afforestation (Souza et al., 2017).

Silveira et al. (2001) proposed mean values for sandy soils cultivated with eucalyptus, where the levels of P (5.6 $\left.\mathrm{mg} \mathrm{dm}{ }^{-3}\right)$, OM (12.0 $\left.\mathrm{g} \mathrm{dm}^{-3}\right), \mathrm{pH}(3.8), \mathrm{K}\left(0.4 \mathrm{mmol}_{\mathrm{c}} \mathrm{dm}^{-3}\right), \mathrm{Ca}\left(2.8 \mathrm{mmol}_{\mathrm{c}} \mathrm{dm}^{-3}\right)$ and $\mathrm{Mg}\left(0.9 \mathrm{mmol}_{\mathrm{c}} \mathrm{dm}^{-3}\right)$ are ideal for the development of the species. The soil chemical levels obtained (Table 1) were below those recommended as levels set by Raij (2011) for agricultural crops and by Gonçalves et al. (2007) for eucalyptus cultivation. In terms of demands for nutrients, clonal species of eucalyptus require low nutrients when compared to most agricultural crops and even in relation to many fast-growing tree species (Rodrigues et al., 2016). However, soil correction is needed when critical nutrient levels are below the recommendations for the species (Guimarães et al., 2015).

The variability of height (HEI) and diameter at breast height (DBH) obtained agree with the results obtained by Rosa Filho et al. (2011), who found $14.4 \%$ of variation when evaluating productivity and soil characteristics in a forest site of Eucalyptus urophylla.

Soil physical attributes varied from low to very high. This way, the granulometric parameters presented low coefficients of variation indication that the soil was homogenous on the other hand, the mean values for gravimetric moisture in both evaluated treatments and soil resistance to penetration in the treatments with limestone and lime sludge + oxyfertil were considered homogeneous and, for the control, heterogeneous, causing a mean value of low significance. Corado Neto et al. (2015), when evaluating the spatial variability of a Entisol, explains that high coefficients of variation are due to variability of soil attributes.

The soil attributes presented high and very high CVs, which, according to Artur et al. (2014) and Lima et al. (2017), is related to alterations caused by irregular fertilization, liming and high heterogeneity of average content of chemical attributes in the evaluated area. Such heterogeneity may have several causes, including soil classification (Entisol), soil formation process and water flow in the area.

In general, the coefficient of variation should be used as a parameter to validate the mean values obtained, since, according to Pimentel-Gomes and Garcia (2002), a coefficient of variation above 30\% indicate the mean is not significant and values above $60 \%$ indicate a very heterogeneous data set, eliminating the reliability of the mean value. However, when below $30 \%$, these data are homogeneous, and the mean value is significant and can be used as representative for the data obtained. However, as proposed by Pimentel-Gomes and Garcia (2002), there is no specificity regarding the nature of the trial/treatments, the culture studied, the attributes analyzed and soil classification, which may be relevant in the interpretation of such measurement, considering that greenhouse experiments are not always associated with low $\mathrm{CV}$, such as studies with vases and low fertility soils, like those found in the Cerrado (Amaral et al., 1997; Martins et al., 2015).

Although the coefficients of asymmetry and kurtosis show the soil attributes have asymmetric distributions, the mean and median values of the studied variables were similar, indicating that data sets do not show marked asymmetry, they are close to a normal distribution. It may indicate that measures of central tendency are not mostly atypical values in the data set (Corado Neto et al., 2015).

The principal component analysis (PCA), which explained $54.96 \%$ of data variability, is in agreement with those observed by Soares et al. (2016), who report that, after this step, the results obtained through a multivariate analysis can be used as the most relevant variables in the characterization and planning of sustainable use of natural environments.

The groups identified by the principal component's analysis were similar to those found by Coscione et al. (2014), which occurred according to the amount of residue applied to the soil, and as in this study, the groups were separated in their respective quadrants, and the control presented groups distributed in all quadrants. Oliveira et al. (2018), when evaluating the spatial variability of chemical and physical characteristics of soils of different textures and different handling, identified groupings for each treatment, except for forest and pasture, which formed a single grouping.

Based on the groups obtained for eucalyptus and soil attributes, the biplot with the main variables, and the spatial distribution of the groups generated for limestone, lime sludge and control, the evaluation of these groups is improved when interrelated to the soil through its interpretation, spatial distribution and correlation with geomorphological properties (Oliveira et al., 2018). 
The biplot that characterized $\mathrm{Al}$ and GM as the attributes that most influence the development of eucalyptus was also observed by Silva et al. (2009), who evaluated the impact of forest plantations using different tree species on physical and chemical characteristics in the Cerrado and found aluminum content, gravimetric moisture and soil porosity as the strongest influence on eucalyptus growth in conventional cultivation.

The grouping of soil classes into homogeneous groups is due to the fact that the applications of limestone and pulp residue for soil correction and alteration of the physical quality of the soil present a more homogeneous and less variable behavior for lime sludge and control (Silva et al., 2010b).

The standardized mean values showed a trend in the areas of higher levels of $\mathrm{Al}$, which also presented lower $\mathrm{Ca}$ and $\mathrm{pH}$ levels and, consequently, lower eucalyptus heights. These data agree with those found by Oliveira et al. (2017), who evaluated the chemical characteristics of an Entisol soil in the Cerrado under different uses and covered with tree species and found that the higher the $\mathrm{Al}$ content in the soil, the lower the $\mathrm{pH}$, resulting in a lower development of tree species.

High levels of Al tended to result in higher eucalyptus development; however, Foy et al. (1978) report that aluminum toxicity can lead to inhibition of cell division, membrane damage, alter DNA synthesis and mitosis, and change cell wall stiffness. However, Silva et al. (2012), when studying eucalyptus resistance to aluminum, found that, depending on the amount of aluminum in the soil, it does not interfere in its development.

In general, multivariate techniques are very important tools as they show relations that cannot be observed through other statistical techniques, suggesting multivariate methods can be used more frequently in different applications.

\section{Conclusions}

The development of Eucalyptus (height and DBH) in sandy soil was satisfactory and can be compared with those grown in clayey soils.

The chemical attributes of the soil presented low levels of fertility in all treatments. The high variability of the physical and chemical characteristics can be attributed to the type of soil (Entisol). The attributes of gravimetric moisture, sand content, clay content, phosphorus content, organic matter, hydrogen potential, calcium content and aluminum content in the soil were the physical and chemical attributes that most influenced the development of eucalyptus, according to a multivariate analysis.

For a more comprehensive understanding of the behavior of soil attributes that may influence the development of eucalyptus, further studies should be conducted to analyze other types of soil and other amounts of soil correctives.

\section{References}

Afzal, S., Nawaz, M. F., Siddiqui, M. T., \& Aslam, Z. (2015). Comparative study on water use efficiency between introduced species (Eucalyptus camaldulensis) and indigenous species (Tamarix aphylla) on marginal sandy lands of Noorpur Thal. Pakistan Journal of Agricultural Sciences, 55(1), 127-135. https://doi.org/10.21162/PAKJAS/18.6626

Albuquerque, J. M., Watzlawick, L. F., Koehler, H. S., \& Longhi, S. J. (2015). Floristic cluster analysis in Araucaria Forest System Faxinal. Brazilian Journal of Applied Technology for Agricultural Science, 8(3), 27-36.

Alvares, C. A., Stape, J. L., Sentelhas, P. C., Gonçalves, J. L., Moraes, G., \& Sparovek, G. (2013). Köppen’s climate classification map for Brazil. Meteorologische Zeitschrift, 22(6), 711-728. https://doi.org/10.1127/ 09412948/2013/0507

Amaral, A. M., Muniz, J. A., \& Souza, M. (1997). Avaliação do coeficiente de variação como medida da precisão na experimentação com citros. Pesquisa Agropecuária Brasileira, 32(12), 1221-1225.

Artur, A. G., Oliveira, D. P., Costa, M. C. G., Romero, R. E., Silva, M. V. C., \& Ferreira, T. O. (2014). Variabilidade espacial dos atributos químicos do solo, associada ao microrrelevo. Revista Brasileira de Engenharia Agrícola e Ambiental, 18(2), 141-149. https://doi.org/10.1590/S1415-43662014000200003

Carvalho, A. P. V., Dias, H. C. T., Paiva, H. N., \& Tonello, K. C. (2012). Resistência mecânica do solo à penetração na bacia hidrográfica do Riacho Fundo, Felixlândia-MG. Revista Árvore, 36(6), 1091-1097. https://doi.org/10.1590/S0100-67622012000600010

Carvalho, R. P., Daniel, O., Davide, A. C., \& Souza, F. R. (2015). Atributos físicos e químicos de um Neossolo Quartzarênico sob diferentes sistemas de uso e manejo. Revista Caatinga, 28(1), 148-159. 
Cheng, J., Ding, C., Li, X., Zhang, T., \& Wang, X. (2016). Soil quality evaluation for navel orange production systems in central subtropical China. Soil and Tillage Research, 155, 225-232. https://doi.org/10.1016/j.still. 2015.08.015

Coelho, A. M. (2005). Agricultura de precisão: Manejo da variabilidade espacial e temporal dos solos e das culturas. In N. Curi, J. J. G. S. M. Marques, L. R. G. Guilherme, J. M. Lima, A. S. Lopes, \& V. H. A. Venegas (Ed.), Tópicos em ciência do solo. Viçosa: SBCS.

Corado Neto, F. D. C., Sampaio, F. D. M. T., Veloso, M. E. C., Matias, S. S. R., Andrade, F. R., \& Lobato, M. G. R. (2015). Variabilidade espacial da resistência à penetração em Neossolo Litólico degradado. Revista Brasileira de Ciência do Solo, 39(5), 1353-1361. https://doi.org/10.1590/01000683rbcs20140692

Coscione, A. R., Silva, L. F. M., Maria, I. C., Andrade, C. A., \& Ferracini, V. L. (2014). Solução do solo e análise de componentes principais para monitoramento da aplicação de lodo de esgoto. Revista Brasileira de Ciência do Solo, 38(5), 1654-1662. https://doi.org/10.1590/S0100-06832014000500030

Coutinho, F. S., Pereira, M. G., Menezes, C. E. G., Guareschi, R. F., \& Assunção, S. A. (2017). Attributes of soil under agriculture, grazing and three succession stages of forest. Floresta e Ambiente, 24(10), 1-11.

EMBRAPA (Empresa Brasileira de Pesquisa Agropecuária). (2017). Manual de métodos de análise de solos (3rd ed.). revisada e ampliada Brasília: Embrapa.

Ferreira, G. W., Roque, J. V., Soares, E. M., Silva, I. R., Silva, E. F., Vasconcelos, A. D. A., \& Teófilo, R. F. (2018). Temporal decomposition sampling and chemical characterization of eucalyptus harvest residues using NIR spectroscopy and chemometric methods. Talanta, 188, 168-177. https://doi.org/10.1016/ j.talanta.2018.05.073

Foy, C. D., Chaney, R. L., \& White, M. C. (1978). The physiology of metal toxicity in plants. Annual Review Plant Physiology, 29(1), 511-566. https://doi.org/10.1146/annurev.pp.29.060178.002455

Freitas, L., Oliveira, I. A., Silva, L. S., Frare, J. C. V., Filla, V. A., \& Gomes, R. P. (2017). Indicadores da qualidade química e física do solo sob diferentes sistemas de manejo. Revista Unimar Ciências, 26(1-2), $8-25$.

Gonçalves, J. L. M., Wichert, M. C. P., Gava, J. L., Masetto, A. V., Junior, A. J., Serrano, M. I. P., \& Mello, S. L. M. (2007). Soil fertility and growth of Eucalyptus grandis in Brazil under different residue management practices. Southern Hemisphere Forestry Journal, 69(2), 95-102. https://doi.org/10.2989/SHFJ.2007. 69.2.4.289

Guimarães, C. C., Floriano, E. P., \& Vieira, F. C. B. (2015). Limitações químicas ao crescimento inicial de Eucalyptus Saligna em solos arenosos do Pampa Gaúcho: Estudo de caso. Ciência Rural, 45(7), 1183-1190. https://doi.org/10.1590/0103-8478cr20120533

Hair, Jr. J. F., Black, W. C., Babin, B. J., Anderson, R. E., \& Tatham, R. L. (2009). Análise multivariada de dados (6th ed.). Porto Alegre: Bookman.

IBÁ (Indústria Brasileira de Árvores). (2017). Relatório IBÁ 2017. Retrieved from https://iba.org/images/shared/ Biblioteca/IBA_RelatorioAnual2017.pdf

Johnson, R. A., \& Wichern, D. W. (2007). Applied multivariate statistical analysis (6th ed.). New Jersey: Pearson Prentice Hall.

Kaiser, H. F. (1958). The varimax criterion for analytic rotation in factor analysis. Psychometrika, 23(3), 187-200. https://doi.org/10.1007/BF02289233

Keesstra, S. D., Bouma, J., Wallinga, J., Tittonell, P., Smith, P., Cerdà, A., ... Fresco, L. O. (2016). The significance of soils and soil science towards realization of the United Nations Sustainable Development Goals. SOIL, 2(2), 111-128. https://doi.org/10.5194/soil-2-111-2016

Khaledian, Y., Kiani, F., Ebrahimi, S., Brevik, E. C., \& Aitkenhead-Peterson, J. (2017). Assessment and monitoring of soil degradation during land use change using multivariate analysis. Land Degradation \& Development, 28(1), 128-141. https://doi.org/10.1002/ldr.2541

Lima, E. S., Montanari, R., Lovera, L. H., Teixeira Filho, M. C. M., \& González, A. P. (2017). Variabilidade espacial das propriedades dendrométricas do eucalipto e atributos químicos de um Neossolo Quartzarênico. Revista de Agricultura Neotropical, 4(1), 1-11. https://doi.org/10.32404/rean.v4i1.1194 
Lopes, J. L. W., Saad, J. C. C., Guerrini, I. A., \& Lopes, C. F. (2011). Crescimento inicial do eucalipto em função da aclimatação em viveiro. Irriga, 16(2), 199-211. https://doi.org/10.15809/irriga.2011v16n2p199

Maciel, T. M. S., Alves, M. C., \& Silva, F. C. (2015). Atributos químicos da solução e do solo após aplicação de resíduo da extração de celulose. Revista Brasileira de Engenharia Agrícola e Ambiental, 19(1), 84-90. https://doi.org/10.1590/1807-1929/agriambi.v19n1p84-90

Maeda, S., Gomes, J. B. V., \& Bognola, I. A. (2015). Crescimento de Eucalyptus benthamii submetido à aplicação de lama de cal e cinza de madeira. Embrapa Florestas: Comunicado Técnico.

Magalhães, R. T., Kliemann, H. J., \& Oliveira, I. P. (2001). Evolução das propriedades físicas de solos submetidos ao manejo do sistema barreirão. Pesquisa Agropecuária Tropical, 31(1), 7-13.

Martins, A. C. F., Schiavini, I., Araújo, G. M. D., \& Lopes, S. D. F. (2015). Capacidade adaptativa de espécies do cerrado utilizadas em áreas de recuperação ambiental. Revista Árvore, 39(3), 543-550. https://doi.org/ 10.1590/0100-67622015000300015

Nogueira Filho, F. P., Bajay, M. M., Sousa, J. A., Araújo, J. D. M., \& Correia, D. (2017). Viabilidade econômica da produção de eucalipto no polo moveleiro de Marco-Ceará. Revista IPecege, 3(4), 22-34. https://doi.org/ 10.22167/r.ipecege.2017.4.22

Oliveira T P, Ensinas S C, Barbosa G F, Nanzer M C, \& Barreta P G V (2017). Atributos químicos de um Neossolo Quartzarênico de cerrado sob diferentes sistemas de uso e manejo. Revista de Agricultura Neotropical, 4(5): 72-78. https://doi.org/10.32404/rean.v4i5.2182

Oliveira, I. A., Freitas, L., Aquino, R. E., Casagrande, J. C., Campos, M. C. C., \& Silva, L. S. (2018). Chemical and physical pedoindicators of soils with different textures: Spatial variability. Environmental Earth Sciences, 77(3), 81-92. https://doi.org/10.1007/s12665-017-7216-2

Paye, H. S., Mello, J. W. V., \& Melo, S. B. (2012). Métodos de análise multivariada no estabelecimento de valores de referência de qualidade para elementos-traço em solos. Revista Brasileira de Ciência do solo, 36(3), 1031-1041. https://doi.org/10.1590/S0100-06832012000300033

Perpetua, G. M., Kröger, M., \& Thomaz, Jr. A. (2017). Agro extractivist corporation's territorial coverage strategies in Latin America: the cellulose industry case in Brazil. Revisit Nera, 20(40), 61-87.

Pimentel-Gomes, F., \& Garcia, C. H. (2002). Estatística aplicada a experimentos agronômicos e florestais: exposição com exemplos e orientações para uso de aplicativos. Piracicaba: Fealq.

R Core Team. (2017). R: A language and environment for statistical computing. R Foundation for Statistical Computing, Vienna, Austria.

Raij, B. V. (2011). Fertilidade do solo e manejo de nutrientes. Piracicaba: IPNI.

Raij, B. V., Andrade, J. C., Cantarella, H., \& Quaggio, J. A. (2001). Análise química para avaliação da fertilidade de solos tropicais. Campinas: IAC.

Reichert, J. M., Suzuki, L. E. A. S., \& Reinert, D. J. (2007). Compactação do solo em sistemas agropecuários e florestais: Identificação, efeitos, limites críticos e mitigação. In C. A. Ceretta, L. S. Silva, \& J. M. Reichert, (Eds.), Tópicos em ciência do solo. Viçosa: SBCS.

Rodrigues, F. A. V., Alvarez, V. V. H., Barros, N. F., Silva, I. R., \& Neves, J. C. L. (2016). Produtividade de eucalipto aos 18 meses de idade, na região do Cerrado, em resposta à aplicação de cálcio, via calcário e gesso agrícola. Scientia Forestalis, 44(109): 67-74. https://doi.org/10.18671/scifor.v44n109.06

Rodriguez, D. R. O., Andrade, G. C., Bellote, A. F. J., \& Tomazello-Filho, M. (2018). Effect of pulp and paper mill sludge on the development of 17-year-old loblolly pine (Pinus taeda L.) trees in Southern Brazil. Forest Ecology and Management, 422, 179-189. https://doi.org/10.1016/j.foreco.2018.04.016

Rosa Filho, G., Carvalho, M. P., Montanari, R., Silva, J. M., Siqueira, G. M., \& Zambianco, C. (2011). Variabilidade espacial de propriedades dendrométricas do eucalipto e de atributos físicos de um Latossolo Vermelho. Bragantia, 70(2), 439-446. https://doi.org/10.1590/S0006-87052011000200027

Schlotzhaver, S. D., \& Littel, R. S. (1997). SAS: System for elementary statistical analysis. Cary: SAS.

Silva, A. S., Lima, J. S. S., Xavier, A. C., \& Teixeira, M. M. (2010a). Variabilidade espacial de atributos químicos de um Latossolo Vermelho-amarelo húmico cultivado com café. Revista Brasileira de Ciência do Solo, 34(1), 15-22. https://doi.org/10.1590/S0100-06832010000100002 
Silva, E. N. S., Montanari, R., Panosso, A. R., Correa, A. R., Tomaz, P. K., \& Ferraudo, A. S. (2015). Variabilidade de atributos físicos e químicos do solo e produção de feijoeiro cultivado em sistema de cultivo mínimo com irrigação. Revista Brasileira de Ciência do Solo, 39(2), 598-607. https://doi.org/10.1590/ 01000683 rbcs 20140429

Silva, L. G. S., Mendes, I. C. M., Reis, Jr. F. B., Fernandes, M. F., Melo, J. T. M., \& Kato, E. (2009). Atributos físicos, químicos e biológicos de um Latossolo de cerrado em plantio de espécies florestais. Pesquisa Agropecuária Brasileira, 44(6), 613-620. https://doi.org/10.1590/S0100-204X2009000600010

Silva, M. D. O. P., Correa, G. F., Coelho, L., \& Rabelo, P. G. (2012). Avaliação de dois tratamentos de adubação em plantio de eucalipto clonal em solo arenoso. Bioscience Journal, 28(1), 212-222.

Silva, M. O., Freire, M. B. G., Mendes, A. M. S., José, F., Campos, M. C. C., \& Amorim, L. B. (2010b). Discriminação de diferentes classes de solos irrigados com águas salinas, na região de Mossoró (RN), com o uso de análise multivariada. Ambiência, 6(2), 261-270.

Silva, P. H. M., Bouillet, J. P., \& Paula, R. C. (2016). Assessing the invasive potential of commercial eucalyptus species in Brazil: Germination and early establishment. Forest Ecology and Management, 374, 129-135. https://doi.org/10.1016/j.foreco.2016.05.007

Silveira, R. L. V. A., Higashi, E. N., Sgarbi, F., \& Miniz, M. R. A .(2001). Seja o doutor do seu eucalipto. Potafós - Informações Agronômicas, 93(12), 1-32. h

Simonete, M. A., Chaves, D. M., Teixiera, C. F. A., Moro, L., \& Neves, C. U. (2013). Fornecimento de cálcio para plantas de Eucalyptus saligna por meio de aplicação de resíduo industrial lama de cal. Revista Brasileira de Ciência do Solo, 37(5), 1343-1351. https://doi.org/10.1590/S0100-06832013000500024

Soares, M. D. R., Campos, M. C. C., Oliveira, I. A., Cunha, J. M., Santos, L. A. C., Fonseca, J. S., \& Souza, Z. M. (2016). Atributos físicos do solo em áreas sob diferentes sistemas de usos na região de Manicoré, AM. Amazonian Journal of Agricultural and Environmental Sciences, 59(1), 9-15. https://doi.org/10.4322/rca. 2020

Souza, E. L. D., Antoniolli, Z. I., Machado, R. G., Pazzini, D. E., Dahmer, S. F., Redin, M., \& Ramires, M. F. (2017). Ectomycorrhizal isolates in the seedling production of Eucalyptus grandis W Hill ex Maiden in Quartzarenic. Neosols. Ciência Florestal, 27(2), 471-484. https://doi.org/10.5902/1980509827729

Statsoft. (2005). Statistica 7.0 Software. Tucksa: Statsoft.

Stolf, R., Murakami, J. H., Brugnaro, C., Silva, L. G., Silva, L. C. F., \& Margarido, L. A. C. (2014). Penetrômetro de impacto Stolf-programa computacional de dados em EXCEL-VBA. Revista Brasileira de Ciência do Solo, 38(3), 774-782. https://doi.org/10.1590/S0100-06832014000300010

\section{Copyrights}

Copyright for this article is retained by the author(s), with first publication rights granted to the journal.

This is an open-access article distributed under the terms and conditions of the Creative Commons Attribution license (http://creativecommons.org/licenses/by/4.0/). 